\title{
THE EFFECT OF PERSON-ORGANIZATION FIT ON JOB SATISFACTION: THE ROLE OF WORKPLACE HAPPINESS
}

\section{BİREY-ÖRGÜT UYUMUNUN İS TATMININE ETKİSI: İŞ YERİ MUTLULUĞUNUN ROLÜ}

\author{
Aslıhan YILDIZ ${ }^{1}$, Hasan Hüseyin UZUNBACAK ${ }^{2}$
}

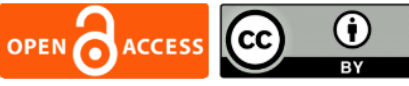

1. Doktora Öğrenci, Süleyman Demirel Üniversitesi, Sosyal Bilimler Enstitüsü, İşletme Anabilim Dalı, Yönetim ve Organizasyon Bölümü,

aslihanyildiz55@gmail.com,

https://orcid.org/0000-0002-3867-0945

2. Doç. Dr., Süleyman Demirel Üniversitesi, İktisadi ve İdari Bilimler Fakültesi, İşletme Bölümü, Yönetim ve Organizasyon Anabilim Dalı, hasanuzunbacak@sdu.edu.tr, https://orcid.org/0000-0002-3297-1659
Makale Türü

Araştırma Makalesi

Başvuru Tarihi

10.04.2021

Yayına Kabul Tarihi 28.07.2021
DOI

Article Type Research Article

Application Date

04.10 .2021

Admission Date 07.28.2021
* Bu araștırma Süleyman Demirel Üniversitesi Sosyal Bilimler Enstitüsü, İșletme Anabilim Dalı, İșletme Yönetim ve Organizasyon Yüksek Lisans Programı'nda, Aslıhan YILDIZ tarafindan, Doç. Dr. Hasan Hüseyin UZUNBACAK danışmanlığında tamamlanan "İş Yerinde Mutluluk Üzerine Bir Araștırma" başlıklı yüksek lisans tez çalışmasından üretilmiştir. Yapılan araştırma, Süleyman Demirel Üniversitesi'nde 17.07.2020 tarihinde sunulmuștur.

\begin{abstract}
In the study, it was aimed to examine the mediating role of workplace happiness in the effect of person-organization fit on job satisfaction. In this context, a literature review on the concepts of happiness, workplace happiness, person-organization fit and job satisfaction was added to the research. The sample of the research consists of 468 white collar employees from 18 enterprises operating in the textile industry in Denizli Organized Industrial Zone. The data procured by using simple sampling method were obtained by making questionnaire to the employees. The survey consists of 20 items about person-organization fit (four items), job satisfaction (five items), workplace happiness (five items), and determining the demographic characteristics of the respondents (6 items). SPSS 22 and AMOS 21 softwares were used in the data analysis of the research. Structural Equation Model was use. It was found out that employees with high person-organization fit experienced higher levels of happiness at work and job satisfaction. In addition, happiness at work had a mediating role between the personorganization fit and job satisfaction.
\end{abstract}

Keywords: Workplace Happiness, Person-Organization Fit, Job Satisfaction, White Collar Employees.

Öz

Araştırmada birey-örgüt uyumunun, iş tatmini üzerindeki etkisinde iş yeri mutluluğunun aracı rolünün incelenmesi amaçlanmıştır. Bu kapsamda mutluluk, iş yeri mutluluğu, birey-örgüt uyumu ve iş tatmini kavramları hakkında literatür taraması yapılarak araştırmaya eklenmiştir. Araştırmanın örneklemi Denizli Organize Sanayi Bölgesi'ndeki tekstil sektöründe faaliyet gösteren 18 işletmedeki 468 beyaz yakalı çalışandan oluşmaktadır. Veriler kolayda örneklem metodu kullanılarak çalışanlardan anket yoluyla elde edilmiştir. Ankette birey-örgüt uyumu 4 madde, iş tatmini 5 madde, is yeri mutluluğu 5 madde ve ankete katılanların demografik özelliklerini belirlemek amacıyla 6 madde olmak üzere toplam 20 maddeye yer verilmiştir. Araştırmanın veri analizinde SPSS 22 ve AMOS 21 programları kullanılmıștır. Hipotezlerin test edilmesinde ise Yapısal Eşitlik Modeli kullanılmıştır. Birey-örgüt uyumu yüksek olan çalışanların iş yerindeki mutluluğunun ve iş tatmininin yüksek olduğu, iş yeri mutluluğu yüksek olan bireylerin de iş tatmininin yüksek olduğu belirlenmiștir. İş yeri mutluluğunun, birey-örgüt uyumu ve iş tatmini arasında aracı rolünün olduğu sonucu elde edilmiştir.

Anahtar Kelimeler: İş Yeri Mutluluğu, Birey-Örgüt Uyumu, İş Tatmini, Beyaz Yakalı Çalışanlar. 


\section{Çalışmanın Amacı}

\section{GENIŞLETILMIŞ ÖZET}

Araştırmanın amacı, Denizli'deki tekstil sektöründe yer alan beyaz yakalı çalışanlar üzerinde birey-örgüt uyumunun, iş tatminine üzerindeki etkisinde iş yeri mutluluğunun aracı rolünü incelemektir.

\section{Araştırma Soruları}

$\mathrm{Bu}$ araştırmada çalışanların birey-örgüt uyumlarının iş tatminlerine ne ölçüde etki ettiği ve aynı zamanda çalışanların bu etkide iş yeri mutluluklarının rolünün ne olduğu sorusuna cevap aranmaktadır.

\section{Literatür Araştırması}

Bireyin gününü geçirdiği, var olduğu, sosyalleştiği, kendini her geçen gün geliştirdiği, hayallerinin peşinden koştuğu, hayatının amacına ulaşmaya çalıştığı işinde ve iş yerinde mutlu olma hayali her birey için bir istek ve bir arzudur (Kjerulf, 2015). İşte bu noktada iş yeri mutluluğu zamanla önemini daha da artıran ve dikkat çeken bir konu haline gelmiştir (Dugdill, 2002; Hickok, 2016; Vanderbilt, 2012). Ancak yapılan araştırmalar, birçok bireyin iş yerinde mutlu olmadıklarını, ayrıca mutluluğun hem bireyler açısından hem de örgütler açısından kayda değer sonuçları olduğunu ortaya çıkarmaktadır (McKee, 2017; Fisher, 2010). Literatüre bakıldığında birey-örgüt uyumu ile iş yeri mutluluğu üzerine Sousa ve Porto (2015) ve Yıldırım (2020) tarafından yapılan yalnızca iki araştırmaya, iş tatmini ile iş yeri mutluluğu üzerine Alparslan (2016) tarafından yapılan yalnızca bir araştırmaya rastlanmıştır. Ancak bu üç değişkenin bir arada incelendiği bir araştırmaya rastlanmamış olup, yapılan bu araştırmanın literatüre katkı sağlayacağı düşülmektedir.

\section{Yöntem}

Araştırmanın evrenini Denizli ili Organize Sanayi Bölgesi'nde tekstil sektörü üzerine faaliyet gösteren 84 işletmedeki 2128 beyaz yakalı çalışan oluşturmaktadır (Denizli Organize Sanayi Bölgesi, 2020). Örneklem ise 18 işletmedeki 468 beyaz yakalı çalışan ile gerçekleştirilmiştir. Bu anlamda araştırmada elde edilen örneklem sayısının evreni temsil yetisine sahip olduğu söylenebilir. Tekstil çalışanlarına dağıtılan toplam 600 anketten 481 adet geri dönüş elde edilmiştir. Hatalı ve eksik kodlama, analiz için yeterli niteliğe sahip olmadığı düşünülen 13 adet anket formu araştırmaya dâhil edilmemiştir. Bu durumda 468 sağlıklı veri ile araştırmaya yön verilmiştir. Araştırmada verilerin toplanmasında anket tekniğinden yararlanılmış ve elde edilen veriler nicel analiz yöntemi uygulanarak test edilmiştir. Araştırma için Süleyman Demirel Üniversitesi Etik Kurulu’ndan gerekli izinler alınarak, çalışanların iş yerleri bizzat ziyaret edilmiş ve anketler elden dağıtılıp ardından toplanmıştır. Toplanan veriler SPSS 22.0 (Statistical Package for Social Sciences) ve AMOS 21 (Analysis of Moment Structures) paket programları ile analiz edilmiştir. Araştırmanın anket formu dört bölümden oluşmaktadır. Anketin ilk bölümünde çalışanların demografik özelliklerini belirlemeye yönelik sorular bulunmaktadır. $\mathrm{Bu}$ bölümde cinsiyet, yaş, medeni durum, eğitim düzeyi, çalışılan birim ve çalışma yılını belirlemek amacıyla toplam 6 soruya yer verilmiş ve 5'li Likert ölçeklendirme (Kesinlikle katılmıorum-1, Kesinlikle katılıyorum-5) kullanılmıştır. İkinci bölümde yer alan Netemeyer ve arkadaşları (1997) 
tarafından geliştirilen birey-örgüt uyumu ölçeği tek boyutlu ve 4 maddeden oluşmaktadır. Ölçeğin Türkçeye uyarlaması Turunç ve Çelik (2012) tarafından yapılmıştır. Üçüncü bölümde Hackman ve Oldham'ın (1975) İş Özellikleri Anketi'nden uyarlanan iş tatmini ölçeği tek boyutlu ve 5 maddeden oluşmaktadır. Ölçeğin Türkçeye uyarlaması Basım ve Şeşen (2009) tarafından yapılmış ve 5'li Likert ölçeklendirme (Kesinlikle katılmıyorum-1, Kesinlikle katılıyorum-5) kullanılmıştır. Son olarak dördüncü bölümde ise WHO Collaborating Center for Mental Health, Frederiksborg General Hospital Psikiyatrik Araştırmalar birimi tarafından oluşturulan iş yeri mutluluğu ölçeği tek boyutlu ve 5 maddeden oluşmaktadır. Ölçeğin Türkçeye uyarlaması Alparslan (2016) tarafından yapılmış ve 6'lı Likert ölçeklendirme (Hiçbir Zaman-1, Her Zaman-5) kullanılmıştır.

\section{Sonuç ve Değerlendirme}

Yapılan istatistiksel analizler sonucunda birey-örgüt uyumunun iş tatmini üzerinde pozitif yönde anlamlı bir etkiye sahip olduğu görülmektedir. Bu bulguya göre birey-örgüt uyumları yüksek olan çalışanların iş tatminlerinin de yüksek olduğu söylenebilir. Yine aynı şekilde birey-örgüt uyumunun iş yeri mutluluğu üzerinde pozitif yönde anlamlı bir etkiye sahip olduğu görülmektedir. Bu bulguya göre birey-örgüt uyumları yüksek olan çalışanların iş yeri mutluluğunun da yüksek olduğu söylenebilir. Araştırma sonuçlarından elde edilen bir diğer bulgu ise iş yeri mutluluğunun, iş tatmini üzerinde pozitif yönde anlamlı bir etkiye sahip olduğudur. Bu bulguya göre iş yeri mutluluğu yüksek olan çalışanların iş tatminlerinin de yüksek olduğu söylenebilir. Yapılan araştırmanın sonucunda, birey-örgüt uyumunun iş tatmini üzerindeki etkisinde iş yeri mutluluğunun aracılık rolü bulunduğu görülmektedir. Birey örgüt uyumu iş tatmini ilişkisinde aracılık rolünün olduğunun ortaya konulmasının literatüre önemli bir katkı sağlayacağ1 düşünülmektedir. 


\section{INTRODUCTION}

Although happiness is a relative concept that differs from individual to individual, the notion of being happy signifies a universal feeling in each individual. Being happy, although known as enjoying life, to be healthy, peaceful, having high social status and financial power, and having every need met for the individual to be satisfied, this situation may differ in each individual. One of the elements that affect the happiness of individuals is business life. Individuals spend most of their time in the workplace in order to maintain their lives, along with those who work although they are sufficient financially and do not need to work. Therefore, the environment in the workplace has a significant impact on individuals.

According to the 2020 World Happiness Report, carried out by the United Nations in consequence of studies conducted about happiness, Turkey, drawing back 14 ranks compared to the previous year, ranks 93 among 156 countries by 5132 points in 2019. According to the data of 2019 Turkish Statistical Institute, on the other hand, it can be said that the rate of people stating that they are happy stands around $52 \%$ but that this rate falls down and unhappy individuals increase every passing year (Turkish Statistical Institute, 2019). In the remaining 48\%, individuals stated that they are not happy. The reason for this can be stated as, based on the working hours of the individuals, some problems in work life may affect their happiness. The concept of happiness has recently attracted the attention of researchers in the field of organizational behavior in Turkey as it does worldwide, and what sort of impact the job has on happiness has been subject to various research (Alparslan, 2016; Güner and Bozkurt; 2017, Uzunbacak and Akçakanat, 2018; Yıldırım, 2020).

As in the past, business life continues to be at the center of an individual's entire life today. The fine line between work and life has almost disappeared. The dream of being happy in the job and workplace of the individual where they spend their days, exist, socialize, improve themselves day by day, pursue their dreams and try to reach the goals of their life is a wish and desire for each individual (Kjerulf, 2015). At this point, workplace happiness has become an issue that increases its importance and attracts attention over time (Dugdill, 2002; Hickok; Vanderbilt, 2012). However, the research reveal that many individuals are not happy in the workplace, and happiness has significant consequences for both individuals and organizations (Fisher, 2010; McKee, 2017).

The research was conducted on textile sector workers in Denizli province. The province of Denizli, which is the first to come to mind not only in Turkey but also in the world when it comes to towels and bathrobes, proves to be ranked first in the textile sector with export figures. The textile sector emerges as a sector that has undertaken almost half of Denizli's exports. Parallel to this, it's part in Denizli's employment is around $25 \%$. In a word, it can be said that one out of every four employees works in the textile sector in Denizli (Denizli Governorship, 2020). While talking about a sector that is of such importance for Denizli, the happiness of the employees in the workplace has been taken under 
research because it is a subject worth examining in detail in terms of their harmony within the organization and their satisfaction with the job.

In this study, firstly, definitions were made about the concepts of workplace happiness, job satisfaction, and person-organization fit, and the relations between variables and theoretical bases were included. Subsequently, in order to reveal the mediating effect of workplace happiness on the effect of person-organization fit on job satisfaction, the findings and results of the application study conducted on white-collar employees of 18 textile companies operating in Denizli Province Organized Industrial Zone were included, the results were evaluated, and the research has been completed with recommendations for subsequent researchers.

\section{CONCEPTUAL FRAMEWORK}

\subsection{The Concept of Happiness}

Happiness, one of the topics of positive psychology, has continued its existence as a purpose, desire, and need throughout human history. Individuals took happiness as a goal for themselves and continued their lives in this direction. While the concept of happiness has been defined in different ways by philosophers and researchers, they expressed happiness as synonymous with subjective well-being and quality of life at the same time. (Fisher, 2010; Sarracino, 2012). The word happiness, which comes from the root "saide" in Arabic, means being happy, strong, and auspicious. While happiness can be defined as a tendency that humans desire all the time but cannot give up, it can also be expressed as attaining goodness, being blissful, and being in states where one can always enjoy themselves (Yıldız, 1997). In the Oxford English Dictionary, the word happiness, "felicita" in Latin comes from the roots of "happen" and "happiness" which come to mean "to happen by chance" and "coincidence" (Marar, 2004). The Current Turkish Dictionary, on the other hand, has defined happiness as "the state of pleasure of achieving all aspirations completely and continuously, happiness, prosperity, auspiciousness, felicity, bliss" (Current Turkish Dictionary, 2019).

Today, individuals continue their lives in a society dominated by postmodernism and constantly pursue new things in an endless path (Bauman, 2011). Continuous pursuit of new things and achieving their goals causes individuals to experience temporary pleasures and these persons are called hedonistic individuals. Although it has been handled in various fields and with different views, the concept of hedonism, widely spoken about throughout history, has its roots in Ancient Greece (Deniz, 2019; Ekin, 2010).

Hedonism is defined as "the doctrine that regards pleasure as the only value and purpose of human life, that all that gives pleasure is good" (Current Turkish Dictionary, 2019). This concept was put forward by Aristippus, who was looking for an answer to the question "what is a happy life", and represented by Epicurus. According to Aristippus' thought, happiness is expressed as the whole of the 
pleasures experienced by the individual. Aristippus, who says that individuals can be happy with their instant pleasures, is of the opinion that people who are after fun, who do not worry about the future, who enjoy the moment they live and always exist with their cheerful attitudes, and who can also control themselves will lead a happy life (Akarsu, 1998).

Another approach belonging to the concept of happiness is eudemonism. Eudemonism is defined as "the moral doctrine that finds the meaning of life in happiness, is based on the view that human behavior is determined by the desire for happiness" (Current Turkish Dictionary, 2019). It is stated that for eudemonism, happiness depends on the personal characteristics and lifestyles of individuals and that happiness is a process (Servet, 2017).

The concept of eudemonism was first put forward by Democritus, who argued that individuals should suppress their personal feelings in order to be happy. Democritus defines eudemonism as a moral philosophy based on the happiness of the individual and trying to bring moral values together in this direction (Aktan, 2009). When individuals want to achieve happiness, they must proceed by predicting whether it will create benefit or futility for them. They can measure this by feelings of pleasure and pain. They should also be able to distinguish what is good in relative and absolute terms. While the things that can be gained with material values such as beauty, fame, and wealth are good in relative terms, good in absolute terms can be explained as the well-being of the individual's soul. When the spiritual peace of the individual is like this, they will be happy with this situation. Again, to achieve happiness, the individual should ensure their spiritual calmness, and on the one hand, should avoid desires that will damage their spiritual calmness (Gökberk, 2008). Based on this, it is possible to interpret happiness as a process that emerges as a result of the interpretation of parts such as family, social environment and especially working life for working individuals, which is also gathered together with the personal characteristics of the individuals, and reflects with positive emotions (Vatandaş, 2017). To summarize, the difference between hedonism and eudemonism approaches is that hedonism suggests that happiness is experienced for a short time, while eudemonism suggests that happiness is experienced continuously and permanently (Field and Buitendach, 2011).

Looking at the studies in the literature, it is stated that, within the framework of the factors that affect happiness, in case of individuals containing positive emotions such as joy, peace, trust, hope, etc. within themselves more, and negative emotions such as sadness, fear, hatred, life anxiety, etc. less, their happiness is ensured (Iş1k et al., 2017). At the same time, individuals' satisfaction with their health, business, or marital life is one of the indicators of happiness (Demirbulat and Avcıkurt, 2015).

Looking at the results of previous studies, the high quality of life of individuals, having real friends, having a compatible marriage, and having a good job is regarded as a sufficient reason for them to be happy. However, it is stated in the literature that work life, which is the most important part of an 
individual's life, affects happiness closely, and research on the relationship between work life and happiness continues. (Iş̧1k et al., 2017).

\subsection{Workplace Happiness}

Happiness in the workplace is a daily activity nourished by the passion for a meaningful purpose, hope for the future, and the friendship of employees in the same environment (McKee, 2017). Workplace happiness can also be expressed as more creativity, rapid career progress, getting more support, achieving a good performance, and establishing strong relationships with colleagues and managers (Pryce-Jones, 2010).

For individuals to continue their lives, it is necessary for them to meet certain physiological needs and to earn money, that is, to work. Besides, the individuals with good financial gain desire to produce something by working, too. Because working meets the desire of the human brain to do something and has become a part of human life (Akduman and Duran, 2017).

In today's business life, individuals work very hard and the business world is changing rapidly, technological developments and globalization proceed with them. While it has been observed in the studies that more than $50 \%$ of working individuals give neutral or negative results in their perspectives on working life, it was determined that $35 \%$ experienced work-related tension, stress, burnout, and sacrificed to work overtime (Veenhoven, 1996). When looking at the research on the concept of happiness in the workplace, there are factors that make employees happy and unhappy (Nazl1, 2015). The top ten elements that make employees happy (Sar1, 2016) are, respectively, the individual liking their job, having friendly and harmonious colleagues, a fair management approach that makes people valuable, strong communication, a fun working environment, a job open to innovation and where one can always improve themselves, having the opportunity to make and implement his own decisions, getting the reward for his labor at the end of the job, and fully comprehending their job.

According to the results of the research conducted by Jones (2010), on the other hand, it is stated that individuals who are happy in the workplace have better health, require a shorter time for motivation, have higher earnings, are more assertive in projects and tasks requiring responsibility, have high creativity, have strong communication with the teammates and organization managers, are more determined, have high learning skills and success rate (as cited in, Akduman, 2015). When we look at the working life of individuals, many factors such as their commitment to their job, their job satisfaction, the fair sanctions of the organization on individuals, the harmony between the individual and the organization, and so on, draw attention. When looking at many studies related to this, it is seen that workplace happiness is referred to with the concepts of job satisfaction and person-organization fit. (Fisher, 2010; Judge, Thoresen, Bono, Paatton, 2001; Moorhead and Griffin, 1989; Sousa and Porto, 2015). 


\subsection{Job Satisfaction}

In today's competitive conditions, organizations have to make some regulations in order to achieve their goals and objectives. In this case, the concept of job satisfaction comes to the fore. There are many definitions of job satisfaction in the literature. Job satisfaction, is expressed as the satisfaction status resulting from the positive emotional perspectives of the employees regarding elements of their job, such as wages, control, working conditions, social relations, and work environment. (Çetin and Basim, 2011). Robbins and Judge (2017) define job satisfaction as the positive emotion that occurs within the individual as a result of job evaluation.

One of the most important factors for individuals to be successful, productive, and happy in their jobs is job satisfaction (Musal et al., 1995). Providing the job satisfaction of individuals is also important in terms of positive reflections of their physical and mental health, and therefore, in terms of ensuring social welfare and happiness in this direction (Poyraz and Kama, 2008). Individuals of a certain age who spend most of their daily lives in the workplace pay attention not only to the economic part of the job they work but also to the psychological aspect of it. Hence, job satisfaction plays an important role in individuals' lives both economically and psychologically (Tümgan, 2007).

Coomber and Barriball (2007) stated that there are many factors that affect job satisfaction and that it is a comprehensive concept in this respect. Therefore, they also stated that these elements differ from individual to individual. When looking at the factors affecting job satisfaction, it is seen that it is divided into two as individual and organizational (Porter and Lawler, 1968). Individual elements are those that depend on the work an individual does. These can be counted as wishes and needs of the individual, talent and personal characteristics, sense of achievement, self-confidence, feedback, and control. Organizational factors, on the other hand, are elements that depend on the organization in which the individual works. And those can be counted as the nature of the job, salary, promotion, reward, colleagues, working conditions, management, policy, and procedures (Glisson and Durick, 1988; Opkara, 2002).

Looking at the individual results of job satisfaction, as job satisfaction directly affects the mental and physical health of the individual, it contributes to the happiness of individuals (Greenberg, 1990). While there is no negative situation within the health of individuals with high job satisfaction, having low job satisfaction causes physical illnesses from psychological-origins such as tension, stress, nausea, headache and stomachache, and alcohol, smoking, and addictive drug use are observed in most individuals (Tzeng, 2002). While the commitment to the organization increases in individuals with high job satisfaction, individuals with low job satisfaction will experience a feeling of reluctance to work and burnout due to exhaustion (Atencio et al., 2003). Looking at the organizational results of job satisfaction, while high performance is observed in organizations where job satisfaction is provided, in organizations where job satisfaction cannot be achieved, the productivity of the organization will decrease as the 
performance of individuals decrease. Therefore, this will affect the success of the organization adversely (Davis, 1988). While individuals show continuity to work in organizations where job satisfaction is provided, individuals' behaviors of coming to the job late and intention to leave the job will increase (Çarıkçı and Oksay, 2004). In organizations where job satisfaction is provided, the labor turnover rate of individuals is low and organizations with such employees can easily find new colleagues if in need. In organizations where job satisfaction cannot be achieved, individuals' labor turnover rate is high, and organizations with such employees find it difficult to find different colleagues (Erdoğan, 1996).

\subsection{Person-Organization Fit}

Although individuals operating in an organization are in an organizational structure to achieve different goals and objectives, individual goals may not comply with the organization's purposes sometimes. One of the main goals of organizations operating today is to ensure the compatibility of employees with the job and the organization (Sarıboğa et al., 2019). According to one view, personorganization fit is achieved when the individual's demands and needs are met by the organization, and according to another viewpoint, when the individual has the abilities to achieve the goals and objectives of the organization (Kristof, 1996). It is also expressed as the cohesion between the expectations, needs and priorities of the employees and the organization (Chatman, 1989).

Person-organization fit is as important as wage, reward, promotion, and working conditions in ensuring the sustainability of the workforce in the business life shaped by certain regulations (Cable and Parsons, 2001). In the formation of some similarity between the value of the employee and the value of the individual, that is, in ensuring person-organization fit, the proximity of the employees with each other, the sharing of feelings and thoughts, is effective in coming together at a closer and common point, and at the same time, the employees making decisions together and proceeding on the same path. However, for those to be implemented, there must be a way chosen by both employees and organizational managers. Therefore, it would be appropriate for organization managers to demonstrate exemplary behaviors to strengthen the workplace friendship of employees (Alparslan et al., 2015).

Van Vianen (2001) classifies the characteristics of person-organization fit by the concepts of personality, value and need. Although the behaviors are similar in some cases, "personality" differs from individual to individual. Elements that make up the personality traits of the individual are skills, temperament, and character structure (Özsoy and Yıldız, 2013). Another feature is the concept of "value". It is one of the most critical points that should be considered within the scope of the organizational value in terms of how individuals will behave in the organization, that is, behaving well or badly. For instance, most of the time, customer satisfaction and justness come to the fore. However, some organizations attach more importance to their employees than to customers. When these two examples are considered, the concept of value explains how individuals should behave in the organization (Özkalp and Kırel, 2001). The concept of "needs" also differs from individual to individual. 
For example, it is observed that unsatisfied needs play a role in experiencing problems such as conflict, psychological problems, theft, and alienation in an organization (Eren, 2017; Ulutaş, 2011).

Person-organization fit, ensuring a harmony achieved by both the individual and the organization, and an ongoing competitive advantage is necessary in order to offer new products, to get back to customers as early as possible, and to benefit from resources efficiently (Özkan et al., 2019). Consequently, when we look at the individual and organizational results of the person-organization fit, in an organization with a person-organization fit, the trust of the employees in each other will increase; as a result of this feeling of trust, strong communication, and strong information sharing will take place between the individual and the organization. Employees will focus more on their work rather than run away from work and will contribute more to the organization. At the same time, compatible employees will be more active, more devoted and more efficient in the organization (Alparslan et al., 2015). In an organization where person-organization fit is achieved, besides the integration of individuals with each other, this harmony will also encourage individuals to work more effectively (Xiaojun and Peilan, 2009). It can be said that individuals with high person-organization fit have positive effects such as less alienation from the organization, low levels of identity confusion, being away from feelings of loneliness and helplessness, and contributing to achieving the goals and objectives set by the organization (Akbaş, 2011). Achieving person-organization fit has a positive effect on the job satisfaction and performance of the employees. However, when this cohesion is not achieved, it is said that job satisfaction decreases and the workforce turnover rate increases on the other hand (Olsen et al., 1995).

\subsection{The Relationship Between Person-Organization Fit and Job Satisfaction}

Scientific determination of the level of person-organization fit plays an important role both in determining the profile of the organization culture and in the recruitment process of individuals who can be qualified as correct regarding the organization (Yahyagil, 2005). In the literature, it is stated that with a high level of person-organization fit, employees' performance and productivity, and stability in the workplace increase to the same extent (Cable and Judge, 1996; O’Reilly, 1991).

Person-organization fit and job satisfaction relationship can be supported by Murray's Need Press Model and Blau's Social Exchange Theory. According to the Need-Print Model, it is stated that the level of harmony between the needs of individuals and the characteristics of the organization results in the satisfaction or suppression of the needs of the individuals (Ostroff and Schulte, 2007 as cited in Bayramlık et al., 2015). It is envisaged that the individual should be included in an organization that will help to meet all their needs and avoid organizations that would pose any obstacle to meeting these needs (Polatç1 and Cindiloğlu, 2013). According to the Social Exchange Theory, since the individuals cannot meet their needs that will provide satisfaction, they interact with other individuals within the organization to meet these needs with the help of an organization (Lawler and Thye, 1999). In this 
context, when the needs of the individual are met, the level of satisfaction increases, and the two parties interact with each other with the efficiency the organization obtained from the individual (Köksal, 2012).

Kristof (1996) stated that in order to achieve person-organization fit, it is essential that both the individual and the organization are happy when their expectations are met. It is assumed that job satisfaction is an effect of the individual's personal and environmental characteristics (O'Reilly et al., 1991). Due to the nature of this effect, the personal characteristics of each individual are different, and thus, the satisfaction levels vary from individual to individual (Scarpello, 1983). Therefore, positive results such as an increase in job satisfaction by keeping individuals together, a decrease in the intention to leave the job, and an increase in organizational commitment may occur in an organization where person-organization fit is provided (Schneider, 2001; Verquer et al., 2003).

To ensure the job satisfaction of the individuals, first of all, organization managers should keep away from the prejudice of seeing the persons as a production factor. In other words, managers should take into account that individuals are not only an economic asset in the organization, they also have social sides, and also, that they operate in the organization to meet their psychological needs. Besides, one of the most important social duties of organizations is to ensure the job satisfaction of individuals (Akınc1, 2002).

\section{$\boldsymbol{H}_{1:}$ Person-organization fit has a positive effect on job satisfaction.}

\subsection{The Relationship Between Workplace Happiness and Job Satisfaction}

With the strengthening of technology day by day, the complexity of organizational structures and operations, and the necessity of individuals to be happy with their work has become a widely accepted fact in the modern business world (Turgut and Çinko, 2017). Organizations have begun to be interested in the positive and negative emotions of the individuals since when individuals whose emotions are ignored and who are regarded as robots become physiologically and psychologically ill after a certain time and their productivity and performance decrease due to troubles. The fact that the issue of employee health and happiness is on the agenda of the World Economic Forum is an indicator of this (Davies, 2016).

As evaluated based on the previous definitions regarding the concept of job satisfaction, job satisfaction reveals how happy an individual is at the job in which they operate (Bozkurt and Bozkurt, 2008). Considering the concepts of happiness and job satisfaction, whether individuals are happy or unhappy affects their work lives and plays an important role in individuals' job satisfaction. Happy individuals positively affect their lives in the workplace and accordingly, the individual's performance in the workplace is also positively affected. As a matter of fact, it is inevitable there to be a positive or negative relationship between individuals' happiness and job satisfaction (Bakan and Büyükmeşe, 2004). 
When the workplace happiness of the individual is considered in terms of Maslow's Hierarchy of Needs, it is assumed that individuals require real needs and their happiness tends to increase when these needs are met (Diener and Lucas, 2000). According to the theory, in order to meet the physiological needs of the individual in the first step of the pyramid, it is necessary to have financial gain first. Therefore, the earnings that the individual gains from the organization they work for will play a significant role in meeting their physiological needs. Regarding his approach, Maslow states that individuals in routine working life must have a safe and comfortable work environment in order to achieve the goals and objectives of the organization and to maximize their motivation (Schepers et al., 2008). When the safety needs are met, the individual becomes happier as a result of operating in a safe organization and that increases the quality of their work (Kula and Çakar, 2015). In this context, the performance of the individuals in an organization where the needs are met, the organizational relations, and communication will be higher and the happiness of the individual at the workplace will increase day by day. In short, it is thought to be the most crucial requirement of the individual in business life for them to be happy and to become aware of themselves as a result of the physical, safety, belonging, esteem, and self-actualization steps.

Job satisfaction is an attitude of the job that emerges as a result of the evaluation of job-related factors. While these attitudes have serious effects on individuals' emotions, it is not difficult to explain what happiness is (Weiss and Cropanzano, 1996). While job satisfaction is within a job-related attitude, happiness in the workplace does not contain only a work-related fact (Ashforth and Humphrey, 1995). Based on this meaning, while happiness can be expressed as the individual's unique emotions, job satisfaction can be expressed as the effect of one's job on themselves. While the individual may be happy at work, they may also have negative feelings towards their job. On the contrary, the individual may feel unhappy in the workplace while feeling positive towards the job (Wright and Doherty, 1998).

\section{$\boldsymbol{H}_{2:}$ Person-organization fit has a positive effect on workplace happiness.}

\subsection{The Relationship Between Person-Organization Fit and Workplace Happiness}

Considering that many employees in today's organizations spend more time with other employees in the workplace than their families, how important social relations are stands out. Harmony is when people interact happily with their environment (Başaran, 2004). Organizational relations, which take place in a large part of employees' lives, have a great effect on meeting the social interaction needs of the individual. Therefore, it is stated that this harmony directly affects the happiness and life quality of the individual (Intelligence, 2014 as cited in, Alparslan et al., 2015).

The values of the individual express everything they desire that will make them happy and find peace (Reichers and Schneider, 1990). Individuals determine their living standards because they are committed to the values they have, and they strive with great ambition to achieve these standards. For example, from various organizations that got back to them for job offers, they prefer the one that fits 
them; and they want to operate in organizations where their values overlap at the maximum level during their work life. The values of the individual determine their attitude, and this affects their behavior. At the same time, other individuals around them are also affected by these attitudes and behaviors (Roberts et al., 2007).

The Social Exchange Theory put forward by Blau (1964) is expressed as mutual requirements that can lead to significant negative consequences when the relationship between the individuals in the organization and the organization that cannot be clearly explained is damaged (Coyle and Conway, 2005). Blau (1964) defines social exchange as absolutely voluntary activities that are formed by the individual gaining motivation with the rewards offered by the organization when individuals have an expectation in return for their output (Aydın, 2017). The theory is trust-oriented, as the individual enters into a situation that does not guarantee positively in the face of their acts as a result of the social exchange. Since it is trust-driven, it also causes feelings such as trust and gratitude in the individual (Blau, 1964). According to the theory, organizations make investments for the happiness of individuals in the workplace and after ensuring that this is understood correctly by individuals, they initiate the social exchange and continue it (Turunç and Çelik, 2010). According to this theory, Organ states that in an organization with happy individuals, individuals' contribution to the organization is more and mutual benefits are more prominent (Organ, 1977 as cited in, Erselcan and Özer, 2018).

Since individuals will feel happier in organizations with a high rate of similarity with their personal characteristics, they want to take part in such organizations and continue there. Likewise, organizations want to work with individuals who are similar to them (Van Vianen, 2000). In order to achieve this harmony, both parties must provide mutual tolerance to each other during the activity process. If the employees do not feel compatible with the organization, individuals will not be attached with the organization, they will be alienated, their job satisfaction will be reduced, and their intention to quit will increase (Sığrı and Gürbüz, 2013). In cases where the person-organization fit is at high levels, individuals try to show more support to each other in the organization. That's why their job satisfaction and organizational commitment increase. Intentions to quit will also be at the lowest levels (Alparslan et al., 2015). Therefore, it can be said that person-organization fit affects workplace happiness since these factors are components of workplace happiness and at the same time individual's happiness in the workplace develops according to these factors.

To summarize, person-organization fit, workplace happiness, and work performance are important issues for employees in organizations. It is important for both parties that organizations that contain organizational beliefs and values, norms, behaviors, and attitudes within themselves should ensue accordance with employees. As this accordance will increase the happiness of the employees, it will also ensure the goals and objectives of the organization are adopted by the employees. As a result, 
the organization will obtain a strong performance from its employees and benefit from the human factor in the highest way (Demirer, 2019).

\section{$\boldsymbol{H}_{3:}$ Workplace happiness has a positive effect on job satisfaction.}

\subsection{The Mediating Role of Workplace Happiness in the Effect of Person-Organization Fit} on Job Satisfaction

Working life is of great importance as it is the center of an individual's life in meeting their needs. The individual will only be satisfied when they meet their needs. Besides, as individuals' performance and productivity at work are among the most important factors affecting the success of organizations, individuals need to be as satisfied as possible from the job they are responsible for in order to keep their performance and productivity at a high level (Toker, 2007). To achieve this satisfaction, it can be said that it is necessary to ensure the person-organization fit in the organization and to have a mutual interaction for both the organization and the individual (Kristof, 1996). Therefore, an increase in the job satisfaction levels of the employees will be seen in an organization with a high person-organization fit (Verquer et al., 2003).

In line with the modern management view, for organizations to achieve effective results, it is necessary to ensure that the job that individuals are looking for and the job is suitable for the individual. It has been determined that for work-individual fit, it is not enough for individuals to be suitable for their job only in terms of individual skills and characteristics and that in some cases, high wages and promotion opportunities provided to the individual cannot provide employee happiness and job satisfaction. Accordingly, research on job satisfaction continue by many researchers today (Erdoğan, 1996). The living conditions of the individuals have an effect on happiness, just like personal characteristics of the individuals directly affecting their happiness. As stated in the Bottom-Up Theory, individuals decide that they are happy or unhappy when their sense of happiness, pleasure and pain they experience independent of their personality traits are evaluated. Therefore, while happiness is formed by the feelings of the individual unique to themselves and their environment, it can be stated that job satisfaction is formed by the effect of the work on the individual (Eryllmaz, 2009). In this context, in an organization where employees operate, it can be said that when the expectations of the individual and the organization are mutually met, and when the individuals are happy at the workplace, the job satisfaction level of the employees will increase.

In the light of this information, it is expected that person-organization fit will positively affect the job satisfaction levels of the employees and thus, the employees will be highly happy with work. For this reason, in this study, workplace happiness is considered as the mediating variable in the effect of person-organization fit on job satisfaction. In this case, the 4th hypothesis of the research was formed as follows. 
$\boldsymbol{H}_{4:}$ Workplace happiness has a mediating effect on the relationship between personorganization fit and job satisfaction.

\section{RESEARCH METHODOLOGY}

In the method part of the research, the purpose and model of the subject researched, the population and sample of the research, the introduction of the scales used, the method and process of data collection, the analysis, and findings of the research are included.

\subsection{Purpose of the Study}

The purpose of the study is to examine the mediating role of workplace happiness in the effect of person-organization fit on job satisfaction on white-collar workers in the textile sector in Denizli. Inspired by the research and theoretical bases in the literature, considering that workplace happiness may have a mediating effect on the relationship between person-organizational fit and job satisfaction, the model of the study was formed as follows.

Figure 1. Research Model

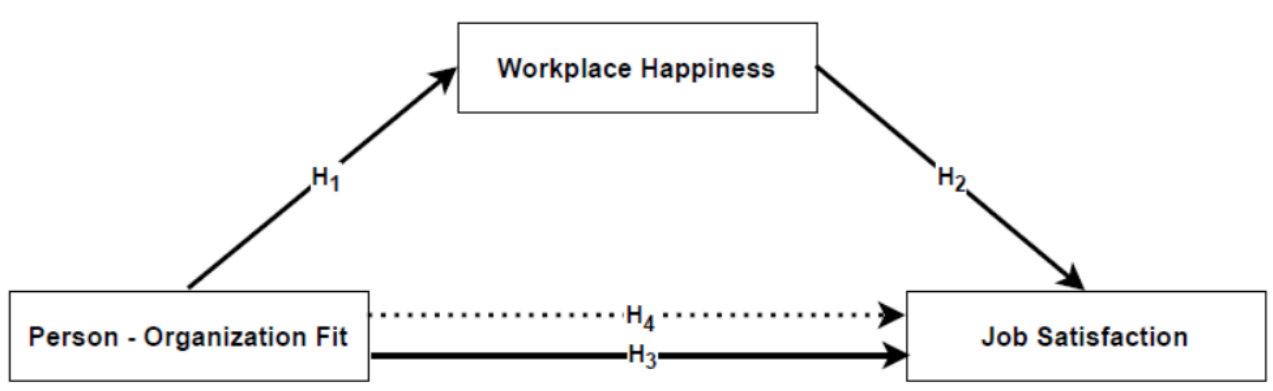

\subsection{Sample of the Research}

The population of the research consists of 2128 white-collar employees of 84 enterprises operating in the textile sector in Denizli province Organized Industrial Zone (Denizli Organized Industrial Zone, 2020). The sample was carried out with 468 white-collar employees of 18 businesses. The convenience sampling method from the sampling methods was used. The purpose of this sampling is to create the sample by the selection of important units in terms of fast and easy availability of the questionnaires (Nakip, 2004).

When the size of the population is certain, the number of people the sample should consist of, the amount of tolerance, and the error probability are calculated according to the size of the population, and a sample of 327 people is considered sufficient when the error tolerance is $5 \%$, the reliability level is $95 \%$, and the population size is 2200 (Krejcie, 1970). In this sense, it can be said that the number of samples obtained in the research can represent the population. 481 responses were obtained from a total of 600 questionnaires distributed to textile employees. 13 questionnaire forms with incorrect and 
incomplete coding that were thought to be insufficient for analysis were not included in the study. In this case, the research was directed with 468 strong data.

\subsection{Research Method and Measures}

The questionnaire technique was used to collect data in the study, and the obtained data were tested by applying the quantitative analysis method. For the research, the necessary permissions were obtained from the Ethics Committee of Süleyman Demirel University, the workplaces of the employees were visited personally, and the questionnaires were distributed by hand and then collected. When there is any item not understood in the questionnaire by the employee, they were informed by explaining, and at the same time, it was stated that the answers given to the questionnaire would in no way be shared with third parties. The collected data were analyzed with SPSS 22.0 and AMOS 21 package software.

The questionnaire form consists of four sections. In the first section of the questionnaire, there are questions to determine the demographic characteristics of the employees. In this section, a total of 6 questions were included in order to determine gender, age, marital status, education level, working unit, and working year. The other three sections consist of scales about person-organization fit, job satisfaction, and workplace happiness, which are introduced below.

Person-Organization Fit Scale: This scale, which was developed by Netemeyer et al. (1997) to measure employees' person-organization fit, is one-dimensional and consists of 4 items. The scale was adapted to Turkish by Turunç and Çelik (2012) and 5-point Likert scaling was used. Employees were asked to tick one of the options: 1: Strongly Disagree, 2: Disagree, 3: Neither agree nor disagree, 4 : Agree, 5: Strongly Agree, expressing to what extent they agree with the sentences on the scale. Reliability coefficient of the original scalewas calculated as .81 and was found to be highly reliable. The high scores obtained from the scales indicate that the person-organization fit of the employees is high. On the scale, there are judgment sentences such as "I think that the values of this institution and my personal values are compatible", "The values of this institution regarding its approach to people are the same as my personal values".

Job Satisfaction Scale: This scale, adapted from Hackman and Oldham's (1975) Job Characteristics Questionnaire to measure the job satisfaction of employees, is one-dimensional and consists of 5 items. The scale was adapted to Turkish by Basım and Şeşen (2009) and 5-point Likert scaling was used. Employees were asked to tick one of the options: 1: Strongly Disagree, 2: Disagree, 3: Neither agree nor disagree, 4: Agree, 5: Strongly Agree, expressing to what extent they agree with the sentences on the scale. Reliability coefficient of the original scalewas calculated as .78 and was found to be quite reliable. The high scores obtained from the scales indicate that the job satisfaction of the employees is high. On the scale, there are judgment sentences such as "My job is like a hobby for me", "I think I'm happier at my job than most other people". 
Workplace Happiness Scale: This scale, which was created by the WHO Collaborating Center for Mental Health, Frederiksborg General Hospital Psychiatric Research Unit to measure the workplace happiness of employees, is one-dimensional and consists of 5 items. The scale was adapted to Turkish by Alparslan (2016) and 6-point Likert scaling was used. Employees were asked to tick one of the options 1: Never, 2: Rarely, 3: Sometimes, 4: Often, 5: Most of the time, 6: Always, expressing to what extent they agree with the judgment sentences on the scale. Reliability coefficient of the original scale was calculated as .83 and was found to be highly reliable. The high scores obtained from the scales indicate that the workplace happiness of the employees is high. On the scale, there are judgment sentences such as "I feel joyful and in high spirits at work", "When I come to work in the morning, I come feeling vigorous".

\section{ANALYSES AND FINDINGS}

The analysis of a total of 468 questionnaire data obtained from employees was carried out using the SPSS 22 package software developed for quantitative research methods. The demographic characteristics of the employees participating in the questionnaire were examined by frequency, percentage and average distributions called descriptive statistics. Then, Internal Consistency Coefficient (Cronbach $\alpha$ ) was calculated to measure the reliability of the scales, and Confirmatory Factor Analysis (CFA) was applied to measure the construct validity of the scales. Also, Structural Equation Modeling was used with the AMOS 21 software and the hypotheses were tested by path analysis.

\subsection{Confirmatory Factor Analysis}

CFA was conducted to test the construct validity of the scales used in the study. The results of the analysis were presented in Table 1. According to these results, it was determined that the scales have excellent goodness of fit values (Hu and Bentler, 1999; Kline, 2011). It is seen that the factor loadings of the Person-Organization Fit Scale items vary between .66 and .93, Job Satisfaction Scale items between .57 and .89 , and Workplace Happiness Scale items between .32 and .87 . On the Workplace Happiness Scale, there is an item with a 32 factor load. Kim-Yin has stated that factor load values were connected with the sample size and thata sample size of at least 350 people would be sufficient to include items with a factor load of .32 in the scale (Kim-Yin, 2004, cited in Şencan, 2005). Therefore, since the sample size of the study is 468 people, the item with a factor load of .30 was included in the scale.

Table 1. Goodness of Fit Values of the Scales

\begin{tabular}{lcccccccc}
\hline Variables & $\chi^{2} / \mathbf{d f}$ & GFI & AGFI & NFI & IFI & TLI & CFI & RMSEA \\
\hline Person-Organization & 4.550 & .995 & .952 & .997 & .997 & .984 & .997 & .087 \\
\hline Job Satisfaction & 2.300 & .990 & .970 & .991 & .995 & .990 & .995 & .053 \\
\hline Workplace Happiness & 1.417 & .994 & .982 & .994 & .998 & .996 & .998 & .030 \\
\hline
\end{tabular}




\subsection{Findings of the Research}

The frequency and percentage values for gender, age, marital status, education level, working unit, and working year of the employees participating in the study are shown in Table 2.

Table 2. Socio-Demographic Findings of Employees

\begin{tabular}{llcc}
\hline & & Number & Percentage \\
\hline \multirow{2}{*}{ Gender } & Woman & 229 & 48.9 \\
& Man & 239 & 51.1 \\
\hline \multirow{2}{*}{ Marital Status } & Married & 301 & 64.3 \\
& Not Married & 167 & 35.7 \\
\hline \multirow{4}{*}{ Education } & Primary & 31 & 6.6 \\
& High School & 116 & 24.8 \\
& Two-Year & 90 & 19.2 \\
& Undergraduate & 219 & 46.8 \\
& Graduate & 12 & 2.6 \\
\hline \multirow{4}{*}{ Working Unit } & Production & 121 & 25.8 \\
& Management & 55 & 11.8 \\
& Finance & 63 & 13.5 \\
& Marketing & 90 & 19.2 \\
\hline Age & Support & 139 & 29.7 \\
\hline Tenure & Avg.=35.1 (SD=7.5) & & \\
\hline Total & Avg.=10.6 (SD=7.6) & 468 & 100 \\
\hline
\end{tabular}

When Table 2 is examined, 229 (48.9\%) of the employees participating in the study are women, and 239 (51.1) are men. When the marital status of the employees was examined, it was seen that 301 (64.3) were married and 167 (35.7) were not. In terms of education levels, 31 (6.6) were graduates of primary school, 116 (24.8) were high school, 90 (19.2) were associate degree, 219 (46.8) were undergraduate, and 12 (2.6) were master's degree. Of the employees, 121 (25.8) are in production, 55 (11.8) in management, 63 (13.5) in finance, 90 (19.2) in marketing, and 139 (29.7) in support units. When Table 2 is examined, the ages of the employees participating in the study ranged from 19 to 63 , with an average age of 35.1 and a standard deviation of 7.499. Looking at the working time, it ranged between 1 and 45, and the average working time was determined to be 10.6 and the standard deviation, 7.571 .

When Table 3 is examined, when the skewness and kurtosis coefficients of the variables are considered, the skewness coefficients are in the value range of .510 and .622 , and the kurtosis coefficients in the value range of -.495 and .022 . Considering these values, it is concluded that the data show a normal distribution. According to Morgan, Leech, Gloeckner, Barret (2004: 49), if the coefficients of skewness and kurtosis are in the range of \pm 1 , the data show a normal distribution.

After the CFA was applied on the validity of the scales and they were determined, reliability analysis was performed to calculate the internal consistency of the scales for the mentioned variables. Here, they were evaluated by looking at the Internal Consistency Reliability Coefficients (Cronbach's 
alpha value). When Table 3 is examined, the Internal Consistency Reliability Coefficient values of the Person-Organization Fit Scale, Job Satisfaction Scale, and Workplace Happiness Scale werefound to be over 80 and highly reliable. Also, the fact that the CR value is above .70, AVE value, above .50, and thatthe CR value is greater than the AVE value shows that convergent validity is achieved (Table 3 ).

Table 3. Descriptive Statistics

\begin{tabular}{lccccccccc}
\hline Variables & Mean & SD & Skewness & Kurtosis & CR & AVE & 1 & 2 & 3 \\
\hline 1. P-O & 3.38 & 1.01 & .510 & -.495 & .90 & .71 & $(.91)$ & & \\
\hline 2. JS & 3.59 & .90 & .588 & .022 & .88 & .61 & $.595^{* *}$ & $(.88)$ & \\
\hline 3. WPH & 4.23 & 1.05 & .622 & .010 & .89 & .57 & $.557^{* *}$ & $.692^{* *}$ & $(.85)$ \\
\hline
\end{tabular}

${ }^{* *} p<.01 ; \boldsymbol{C R}$ : Composite reliability, $\boldsymbol{A} \boldsymbol{V E}$ : Average variance extracted, SD: Standard deviation, P-O: Person-Organization Fit, JS: Job Satisfaction, WPH: Workplace Happiness

When the person-organization fit of the employees is examined in Table 3, it is seen that they have an average of 3.38 ( $\mathrm{SD}=1.01)$. Considering that the maximum score that can be obtained from each item in the scale related to the variable is 5 , it can be said that the employees show a personorganization fit above the medium level. When job satisfaction is examined, it is seen that the average is $3.59(\mathrm{SD}=.90)$. Considering that the maximum score that can be obtained from each item in the scale for the variable is 5 , it indicates that the employees have job satisfaction above the medium level. Finally, when their workplace happiness is examined, it is seen that the average is $4.23(\mathrm{SD}=1.05)$. Considering that the maximum score that can be obtained from each item in the scale related to the variable is 6 , it is concluded that the employees have workplace happiness above the average level.

When Table 3 is examined, there is a moderate, positive and significant correlation between person-organization fit and job satisfaction $(\mathrm{r}=.595, \mathrm{p}<.01)$ and workplace happiness $(\mathrm{r}=.557, \mathrm{p}<.01)$. In this case, it can be said that as the person-organization fit increases, job satisfaction and workplace happiness will also increase. There is a medium level, positive and significant correlation between job satisfaction and workplace happiness $(r=.692, p<.01)$. In this case, it can be interpreted that as job satisfaction increases, workplace happiness also increases.

\subsection{The Hypothesis Test Results}

In order to test the hypotheses in the study, the structural equation model was applied. Therefore, the relationships presented in the form of hypotheses were analyzed with the AMOS 21 software. As a result of the path analysis, the model shown in Figure 2 was formed. In testing the structural equation models, the maximum likelihood method and resampling method were used, and analyzes were made over 5000 resamples. For the significance of the mediating effect, the lower and upper limit confidence interval values in the $95 \%$ confidence interval were examined. It is understood that these values do not include the value of zero (0), and it can be said that the mediating effect is statistically significant (MacKinnon et al., 2004). 
Figure 2. Path Analysis

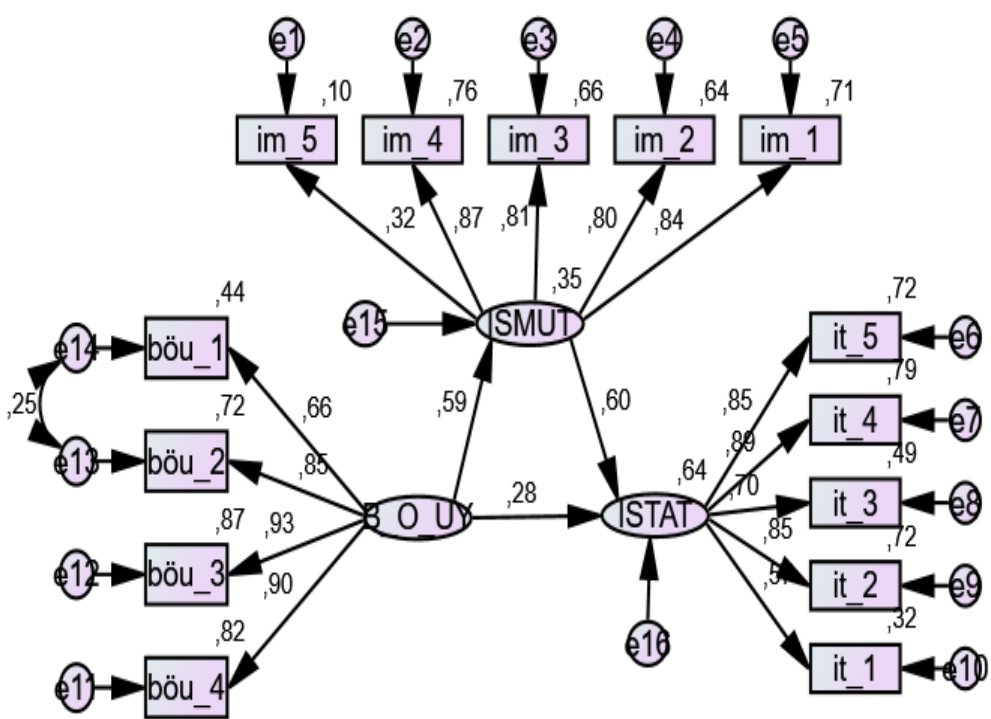

A modification was made between e13 and e14 during the path analysis. The reason for this modification was deemed appropriate to ensure that the goodness of fit value of the model was within acceptable limits. According to the goodness of fit values of the structural equation model ( $\chi 2$ / df: 2.332; $\mathrm{p}<.001 ; \mathrm{CFI}=.98 ; \mathrm{NFI}=.96 ; \mathrm{TLI}=.97 ; \mathrm{GFI}=.95 ;$ AGFI..93; RMSEA: .053) in Figure 2, the model indicates perfect fit (Hu and Bentler, 1999; Kline, 2011).

The standardized path coefficients obtained as a result of testing the structural model are given in Table 4.

Table 4. Path Analysis Results

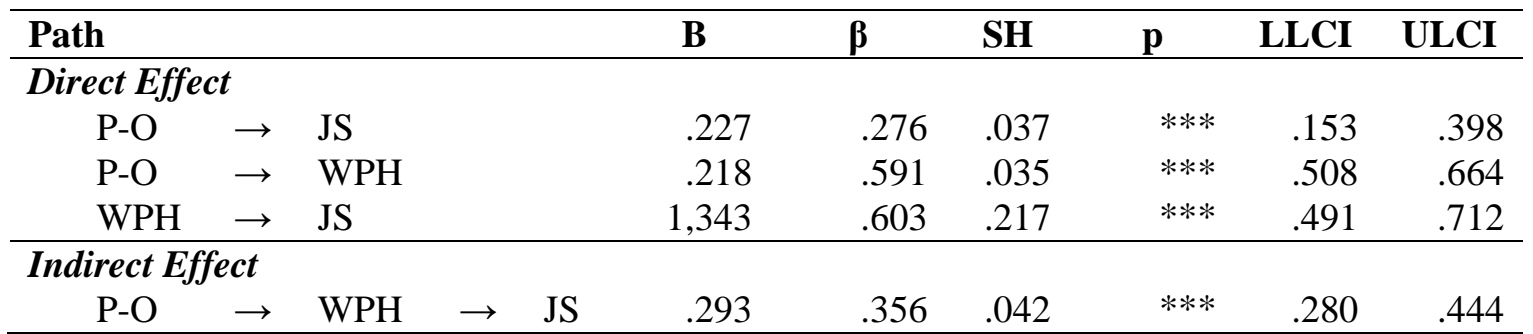

Note: ${ }^{* * *} \mathrm{p}<.001$; B: Unstandardized regression coefficient; $\boldsymbol{\beta}$ : Standardized regression coefficient; $\mathbf{S E}$ : Standard error; LLCI: Lower limit confidence interval; ULCI: Upper limit confidence interval; P-O: Person-Organization Fit; JS: Job Satisfaction; WPH: Workplace Happiness

When Table 4 is examined, it is seen that the effect of person-organization fit on job satisfaction is positive and significant $(\beta=.276, \mathrm{p}<.001)$ and that person-organization fit and workplace happiness have a share of $64 \%\left(R^{2}=.64\right)$ in explaining job satisfaction. In this context, the $H_{l}$ hypothesis of the research was supported. It was understood that the effect of person-organization fit on workplace happiness is positive and significant $(\beta=.591, \mathrm{p}<.001)$ and that person-organization fit has a share of $35 \%\left(R^{2}=.35\right)$ in explaining workplace happiness. In addition, it is seen that workplace happiness, again, affects job satisfaction $(\beta=.603, \mathrm{p}<.001)$ positively and significantly. These results also support the $\mathrm{H}_{2}$ 
and $H_{3}$ hypotheses. According to the results regarding the mediation effect, it is seen that workplace happiness has a mediating role in the effect of person-organization fit on job satisfaction, and its indirect effect is significant $(\beta=.356, \mathrm{p}<.001,95 \%$ BCA CI $[.280, .444])$, and the hypothesis numbered $H_{4}$ has been accepted.

\section{CONCLUSION AND DISCUSSION}

Workplace happiness remains one of the issues that organization managers and organization employees attach importance to recently. Many working individuals spend most of their time at work. The work that the individuals do in order to maintain their life, achieve their goals and actualize themselves and the workplace where they perform this play an important role in the individuals' private life. At the same time, it can be said that the happiness of the individual in the workplace depends on the harmony within the organization and the individual's sense of satisfaction.

As a result of the statistical analysis made, it is seen that the person-organization fit has a significant and positive effect on job satisfaction. According to this finding, it can be said that employees with high person-organization fit also have high job satisfaction. Looking at the literature, the results reached in this study comply with the results of the studies conducted by Lim et al., (2019), Sökmen and Bıyık (2016), Karamanlığlu et al., (2019). Again, correlatively, it is seen that person-organization fit has a significant and positive effect on workplace happiness. According to this finding, it can be said that employees with high person-organization fit also have high workplace happiness. Looking at the literature, only two studies, done by Sousa and Porto (2015) and Y1ldırım (2020), on these two variables have been found, and this is in line with the results of this study. Another finding obtained from the research results is that workplace happiness has a positively significant effect on job satisfaction. According to this finding, it can be said that employees with high workplace happiness also have high job satisfaction. Looking at the literature, only one study where the relevant variables were measured together was found and the results of this study are similar to the results of the study conducted by Alparslan (2016). As a result of the research done, it is seen that workplace happiness has a mediating role in the effect of person-organization fit on job satisfaction. It is thought that revealing that there is a mediating role in the relationship between person-organization fit and job satisfaction will make a significant contribution to the literature. This study is of great importance for both researchers and managers, especially since there are no studies in the national and international literature on the role of employees' workplace happiness in the relationship between person-organization fit and job satisfaction.

In the evaluation of workplace happiness, it was concluded that $14.7 \%$ of the employees were happy at a low level, $72 \%$ at a medium level, and $13.3 \%$ at a high level. In this context, although it is concluded that $85.3 \%$ of the employees are happy on a medium or high level, it cannot be said that the majority of the employees are completely happy. Many factors such as workflow in the workplace, the 
job itself, the salary, department, compatibility between employees, and fair management do not fully meet the satisfaction level of the employees. For these reasons, although employees do not always feel joyful and pleasant at work, it can be said that they are satisfied with working in their workplace in general. Looking at the remaining $14.7 \%$, it is seen that the low level of happiness of the employees is generally due to their irritable and tense mood at work. The reasons for this can be that the employees are not satisfied with the job, they do not enjoy the job, their views on personal value and justice do not comply with the organization. Therefore, considering these results, it is understood that the textile industry needs studies for understanding how organizations can contribute to workplace happiness. In particular, it is thought that organization managers' detailed investigation of the underlying reasons for the low job satisfaction levels of employees and efforts to increase the level of person-organization fit will make a significant contribution in terms of both employees and the sector.

\section{LIMITATIONS OF THE RESEARCH AND RECOMMENDATIONS}

As in every research, this research has some limitations. First of all, since the sample of this research consists of white-collar workers of 18 enterprises operating in the Denizli Organized Industrial Zone, the generalizability of the study can be limited by the white-collar workers of all the textile businesses in Turkey. At the same time, it is not possible to make any generalizations for different sectors and occupational groups since the research is only examined on the textile sector. Therefore, the effect of person-organization fit on job satisfaction and the mediating role of workplace happiness in different sectors and occupational groups will also differ. In addition, the fact that the model in the research should be examined with different and various variables can be stated as a limitation, too.

The research area is limited to the Organized Industrial Zone, which includes various sectors. Another reason for preferring this region is that it has faster and easier access to businesses. In addition, the fact that other textile enterprises in the region could not spare time for the survey and that permission cannot be requested due to their business policies made it difficult to collect data and therefore these enterprises could not be included in the scope of the research. Research data were collected between January and February 2020 and the research findings can only give an idea for the relevant period. The data of the variables of the study are limited to the scope of the scales used. Since employees personally evaluate and respond to person-organization fit, job satisfaction, and workplace happiness, they bring along social desirability bias problems. For this reason, in other studies, while the scales of the relevant variables are interpreted by the individuals, the interpretations of the individuals by their colleagues may also be examined.

In the light of research findings and information obtained from the literature, the recommendations of the research conducted to increase workplace happiness can be counted as strengthening the relationship between the individual and the organization, exhibiting fair behavior within the organization, giving place to happiness activities, doing works that will increase motivation, 
and including training based on innovation. The suggestions of the research for researchers are: When the results of the study are examined, it is seen that the person-organization fit has a share of $35 \%$ in explaining the workplace happiness. Thus, it is suggested to include different and more variables such as organizational commitment, organizational justice, organizational silence, intention to quit, mobbing in future studies of workplace happiness. Since this research was conducted only on white collar workers in the textile industry, it is not possible to make any generalizations. It is thought that future studies will contribute to the literature by being conducted in a wider population, including blue-collar workers in different sectors. Besides, evaluating the perception of happiness among the sectors will provide different perspectives on what is happiness in the workplace and what affects this happiness. The qualitative research method was used in this study. In this respect, supporting the research with qualitative methods will increase the possibility of presenting generalizable results from the research. It is based on a cross-sectional research design because participants' perception of happiness in the workplace is evaluated only in a certain period of time, and therefore, it may be suggested to collect data in different periods by making a longitudinal research design in future studies. Since the data of this research were collected before Covid-19, the relevant variables are recommended to be applied after Covid-19 in the same sector, and it is thought that the results of the research will contribute to the literature in terms of revealing the difference between both periods.

\section{REFERENCES}

Akarsu, B. (1998). Mutluluk ahlakl: Ahlak öğretileri-I. İstanbul: İnkılap Yayınevi.

Akbaş, T. T. (2011). Algılanan kişi-örgüt uyumunun örgütsel vatandaşlık davranışları üzerindeki etkisi: Görgül bir araştırma. Yönetim Bilimleri Dergisi, 9(1), 56-81.

Akduman, G. (2015). Çalışan mutluluğunun işe iliş̧kin duyuşsal iyilik algısı ile ilişskisi ve kuşaklar arasındaki farklılıkların incelenmesi. (Doktora Tezi). Erişim adresi Ulusal Tez Merkezi https://tez.yok.gov.tr/UlusalTezMerkezi/tezSorguSonucYeni.jsp

Akduman, G. and Duran, N. (2017, Nisan). Organizasyonlarda çalışan mutluluğunun önemi ve insan kaynaklarında yeni bir kavram: Mutluluk departmanı. Uşak Uluslararası Sosyal Araştırmalar Kongresinde sunulan bildiri http://naimesimsek.yuksekbilgili.com/wordpress/wp-content/uploads/2017/10/bildirikitapcigi_Cilt_I.pdf

Akıncı, Z. (2002). Turizm sektöründe işgören iş tatminini etkileyen faktörler: Beş yıldızlı konaklama işletmelerinde bir uygulama. Akdeniz İ.I.B.F. Dergisi, 4, 1-25.

Aktan, C. C. (2009). Ahlak ve ahlak felsefesine giriş. Hukuk ve İktisat Araştırmaları Dergisi, 1(1), 38-59.

Alparslan, A. M. (2016). Emek işçilerinde fazladan rol davranışının öncülü: İş tatmini mi işyerinde mutluluk mu? Atatürk Üniversitesi İktisadi ve İdari Bilimler Dergisi, 30(1), 203-215.

Alparslan, A. M., Çiçek, H. and Soydemir, S. (2015). Birey-örgüt uyumunu güçlendiren öncül: İşyeri arkadaşlı̆̆ı. Akdeniz I.I.I.B.F. Dergisi, 32, 175-194.

Ashforth, B. E. and Humphrey, R. H. (1995). Labeling processes in the organization. Research in Organizational Behavior, 17, 413-61. 
Atencio, B. L., Cohen, J. and Gorenberg, B. (2003). Nurse retention: Is it worth it?", Nurse Econ, 21(6), 262-268.

Aydın, E. (2017). Kültür bağlamında sosyal mübadele: Kuramsal bir çalışma. Uluslararası İktisadi ve İdari İncelemeler Dergisi, 547-562.

Bakan, İ. and Büyükbeșe, T. (2004). Örgütsel iletișim ile iș tatmini unsurları arasındaki ilișkiler: Akademik örgütler için bir alan araştırması. Akdeniz Üniversitesi İktisadi ve İdari Bilimler Fakültesi Dergisi, 4(7), 1-30.

Basım, H. N. and Şeşen, H. (2009, Mayıs). Örgütsel adalet algısı-örgütsel vatandaşlık davranıș1 ilișkisinde iș tatmininin aracılık rolü. 17.Yönetim ve Organizasyon Kongresi'nde sunulan bildiri. http://w3.balikesir.edu.tr/ seymen/yonetim.pdf

Başaran, İ. E. (2004). Yönetimde insan iliş̧kileri yönetsel davranış (3. Bask1). Ankara: Nobel Yayıncilık.

Bauman, Z. (2011). Yaşam sanatı. (Çev. Sar1, A). İstanbul: Versus Kitap.

Bayramlık, H., Bayık, M. E. and Güney, G. (2015). Kişi-örgüt uyumunun iş tatmini üzerine etkisi: Ankara ilinde iş makineleri sektörü işgörenleri üzerinde bir uygulama. Kara Harp Okulu Bilim Dergisi, 25(2), 1-28.

Blau, P. (1964). Exchange and power in social life. New York: Wiley.

Bozkurt, Ö. and Bozkurt, İ. (2008). İş tatminini etkileyen işletme içi faktörlerin eğitim sektörü açısından değerlendirilmesine yönelik bir alan araştırması. Doğuş Üniversitesi Dergisi, 9(1), 1-18.

Cable, D. M. and Judge, T. A. (1996). Person-organization fit, job choice decisions and organizational entry. Organizational Behavior and Human Decision Processes, 67(3), 294-311.

Cable, D. M. and Parsons, C. K. (2001). Socialization tactics and person-organization fit. Personnel Psychology, 54(1), 123.

Chatman, J. A. (1989). Improving interactional organizational research: A model of personorganization fit. Academy of Management Review, 114(3), 333-349.

Coomber, B. and Barriball, K. L. (2007). Impact of job satisfaction components on intent to leave and turnover for hospital-based nurses: a review of the research literature. International Journal of Nursing Studies, 44(2), 297-314.

Coyle-S., J. A. M. and Conway, N. (2005). Exchange relationships: examining psychological contracts and perceived organizational support. Journal of Applied Psycholog, 90(4), 774-781.

Current Turkish Dictionary, Access address (2019), https://sozluk.gov.tr/

Çarıkçı, İ. H. and Oksay, A. (2004). Örgütsel yapı ve meslek farklılıklarının iş tatmini üzerindeki etkileri: Hastane çalışanları üzerine bir araştırma. Süleyman Demirel Üniversitesi İktisadi ve İdari Bilimler Fakültesi Dergisi, 9(2), 157-172.

Çetin, F. and Basım, N. (2011). Psikolojik dayanıklılı̆̆ın iş tatmini ve örgütsel bağl1lık tutumlarındaki rolü. İ̧̧GÜÇ Endüstri İlişkileri ve İnsan Kaynakları Dergisi, 13(3), 8194.

Davies, W. (2016). The happiness industry. London: Verso.

Davis, K. (1988). İşletmede insan davranışı-Örgütsel davranış (Çev. Tosun, K). İstanbul: İstanbul Üniversitesi İşletme Fakültesi Yayını. 
Demirbulat, Ö. and Avcıkurt, C. (2015). Turizm ve mutluluk arasındaki ilişki üzerine kavramsal bir değerlendirme. Ballkesir University The Journal Of Social Sciences Institute, 18(34), 79-97.

Demirer, C. M. (2019). Kişi örgüt uyumunun iş performansı üzerine etkisi: Mutluluğun aracılık rolü. Atatürk Üniversitesi İktisadi Ve İdari Bilimler Dergisi, 33(1), 283-302.

Deniz, A. K. (2019). Dijital çağın hedonist çalışanları: Dijital göçebeler. IBAD Sosyal Bilimler Dergisi, (5), 101-113.

Denizli Organize Sanayi Bölgesi, https://www.dosb.org.tr/firmalar/firmalarimiz

(2020) Erişim adresi

Denizli Valiliği, 2020 Erişim adresi http://www.denizli.gov.tr/tekstil-sektoru

Diener, E. and Lucas, E. R. (2000). Explaining differences in societal levels of happiness: Relative standards, need fulfillment, culture, and evaluation theory. Journal of Happiness Studies, 1(1), 41-78.

Dugdill, L. (2002). Developing a holistic understanding of workplace health: The case of bank workers. (Eds. Reilly, T. ve Greeves, J). London: Routledge.

Ekin, V. (2010). Tüketim toplumu, hedonizm ve araç olarak yazılı basın. (Doktora Tezi). Erişim adresi Ulusal Tez Merkezi https://tez.yok.gov.tr/UlusalTezMerkezi/tezSorguSonucYeni.jsp

Erdoğan, İ. (1996). İşletme yönetiminde örgütsel davranış. İstanbul: İşletme Fakültesi Yayını.

Eren, E. (2017). Örgütsel davranıs ve yönetim psikolojisi. İstanbul: Beta Basım Yayım.

Erselcan, R. C. and Özer, P. S. (2018). İş doyumunun performansa etkisinde mutluluğun aracılık rolü üzerine bir araştırma. Girişimcilik ve Kalkınma Dergisi, 13(2), 148-165.

Ery1lmaz, A. (2009). Ergen öznel iyi oluş ölçeğinin geliştirilmesi. Türk Eğitim Bilimleri Dergisi, 7(4), 975-989.

Field, L. K. and Buitendach, J. H. (2011). Happiness, work engagement and organisational commitment of support staff at a tertiary education institution in South Africa. $S A$ Journal of Industrial Psychology, 37(1), 01-10.

Fisher, D. C. (2010). Happiness at work. International Journal Of Management Reviews, 12(4), $384-412$.

Glisson, C. and Durick, M. (1988). Predictors of job satisfaction and organizational commitment in human service organizations. Administrative Science Quarterly, 61-81.

Gökberk, M. (2008). Felsefe tarihi. İstanbul: Remzi Kitabevi.

Greenberg, J. (1990). Employee theft as a reaction to underpayment inequity: The hidden cost of pay cuts. Journal of Applied Psychology, 75, 561-599.

Güner, F. and Bozkurt, Ö. Ç. (2017). Banka çalışanlarının işyerinde mutluluk ve mutsuzluk nedenleri üzerine keşif amaçlı bir araştırma. Örgütsel Davranış Araştırmaları Dergisi, 2(2), 85-105.

Hickok, D. (2016). The pursuit of happiness at work: For entrepreneurs, and the people who work for them. USA: Blue Pool Media.

Hu, L. and Bentler, P. M. (1999). Cut off criteria for fit indexes in covariance structure analysis: Conventional criteria versus new alternatives. Structural Equation Modeling: A Multidisciplinary Journal, 6(1), 1-55.

Işık, Z., Çetinkaya, N. and Işık, M. F. (2017). Mutluluğun iş tatmini üzerindeki rolü: Erzurum ili palandöken kış turizm merkezinde yer alan konaklama işletmelerindeki kadın 
çalışanlar üzerine bir uygulama. Atatürk Üniversitesi Sosyal Bilimler Enstitüsü Dergisi, 21(2), 457-471.

Judge, T.A, Thoresen, C.J, Bono, J.E. and Patton, G. K. (2001). The job satisfaction-job performance relationship: A qualitative and quantitative review. Psychological Bulletin, 127(3), 376.

Karamanlıoğlu, A. U., Güner, G., Bahadır, B. E. and Yeloğlu, H. O. (2019). Kişi-örgüt uyumunun işten ayrılma niyeti üzerine etkisinde iş tatmini nasıl bir aracılık rolü üstlenir? Görgül bir çalışma. Business \& Management Studies: An International Journal, 7(3), 26-39.

Kjerulf, A. (2015). Sabah 9'dan akşam 6'ya happy hour: İs yerinde nasıl mutlu olunur? (Çev. Yapalak, C). (1. Baskı). İstanbul: Doğan Egmont Yayıncılık.

Kline, R. B. (2011). Principles and practice of structural equation modeling (3rd ed.). New York: Guilford.

Köksal, O. (2012). Sosyal değişim teorisi çerçevesinde güven ve algllanan aidiyet durumunun örgütsel vatandaşlık davranışı ve saldırgan davranışlar üzerindeki etkisi. (Doktora Tezi). Erișim adresi Ulusal Tez Merkezi https://tez.yok.gov.tr/UlusalTezMerkezi/tezSorguSonucYeni.jsp

Krejcie, R. V. and Morgan, D. W. (1970). Determinning sample size for research activities. Educational and Psychological Measurement, 30, 607-610.

Kristof, A. L. (1996). Person-organization fit: An integrative review of its conceptualizations, measurement, and implications. Personnel psychology, 49(1), 1-49.

Kula, S. and Çakar, B. (2015). Maslow ihtiyaçlar hiyerarşisi bağlamında toplumda bireylerin güvenlik algısı ve yaşam doyumu arasındaki ilişki. Bartın Üniversitesi IIBFF Dergisi, 6(12), 191-210.

Lawler, E. J. and Thye, S. R. (1999). Bringing emotions into social exchange theory. Annual Review of Sociology, 25, 217-244.

Lim, S., Lee, K. H., and Bae, K. H. (2019). Does Person-Organization Fit Mediate the Relationship between Affect-Based Work Antecedents and Public Employee Job Satisfaction? Journal of Public and Nonprofit Affairs, 5(2), 134-154.

MacKinnon, D. P., Lockwood, C. M. and Williams, J. (2004). Confidence limits for the indirect effect: Distribution of the product and resampling methods. Multivariate behavioral research, 39(1), 99-128.

Marar, Z. (2004). Mutluluk paradoksu: Özgürlük ve onaylanma. (Çev. Çağlayan, S). İstanbul: Kitap Yayınevi.

McKee, A. (2017). İş'te nasıl mutlu olunur? (Çev. Altınyeleklioğlu, D). İstanbul: Park Yayınlar1.

Moorhead, G. and Griffin, R. W. (1989). Organizational behavior. Boston: Houghton and Mifflin Company.

Morgan, G. A., Leech, N. L., Gloeckner, G. W. and Barret, K. C. (2004). SPSS for introductory statistic: Use and interpretation. (2rd ed). London: Lawrance Erlbaum Associates Publishers.

Musal, B., Elçi, Ö. and Ergin, S. (1995). Uzman hekimlerde mesleki doyum. Toplum ve Hekim Dergisi, 68, 2-7.

Nakip, M. (2004). Pazarlama araştırmalarına giriş (spss destekli). Ankara: Seçkin Yayıncılık. 
Nazlı, M. (2015). Hizmet sektöründe kurumsal yönetimin işte mutluluk üzerine etkisi. (Doktora Tezi). Erişim adresi Ulusal Tez Merkezi https://tez.yok.gov.tr/UlusalTezMerkezi/tezSorguSonucYeni.jsp

Olsen, D., Maple, S. and Stage, F.K. (1995). Women and minority faculty job satisfaction professional role interests professional satisfactions and institutional fit. Journal of Higher Education, 66(3), 267-293.

O`Reilly, C. A., Chatman, J. and Caldwell, D. F. (1991). People and organizational culture: A profile comparison approach to assessing person-organization fit. Academy of Management Journal, 34(3), 487-516.

Özkalp, E. and Kırel, Ç. (2001). Örgütsel davranış. Eskişehir: Anadolu Üniversitesi Eğitim Sağlık ve Bilimsel Araştırma Çalışmaları Vakfı.

Özkan, O. S., Tolga, O. M. A. Y. and Akyüz, G. A. (2019). Psikolojik sermaye, bireysel performans ve birey-örgüt uyumu: Bir literatür taraması. Selçuk Üniversitesi Sosyal Bilimler Enstitüsü Dergisi, 41, 113-126.

Özsoy, E. and Yıldız, G. (2013). Kişilik kavramının örgütler açısından önemi: Bir literatür taraması. İsletme Bilimi Dergisi, 1(2), 1-12.

Polatcı, S. and Cindiloğlu, M. (2013). Kişi-örgüt uyumunun örgütsel vatandaşlık davranışına etkisi: Duygusal bağlılığın aracılık rolü. Süleyman Demirel Üniversitesi İktisadi ve İdari Bilimler Fakültesi Dergisi, 18(3), 299-318.

Porter, L. and Lawler, E. (1968). Managerial attitudes and performance, homewood. Illinois: The Dorsey Press.

Poyraz, K. and Kama, B. (2008). Algılanan iş güvencesinin, iş tatmini, örgütsel bağlllık ve işten ayrılma niyeti üzerindeki etkilerinin incelenmesi. Süleyman Demirel Üniversitesi İktisadi ve İdari Bilimler Fakültesi Dergisi, 13(2), 143-164.

Pryce-Jones, J. (2010). Happiness at work: Maximizing your psychological capital for success. United Kingdom: Wiley-Blackwell.

Reichers, A. E. and Schneider, B. (1990). Climate and culture: An evolution of constructs. Organizational Climate and Culture, 1(1), 1-39.

Robbins, S. P. and Judge, T. A. (2017). Örgütsel davranı̧. (Çev. Erdem, İ). (14. bask1). Ankara: Nobel Akademik Yayıncılık.

Roberts, B. W., Kuncel, N., Shiner, R. N., Caspi, A. and Goldberg, L. R. (2007). The power of personality: The comparative validity of personality traits, socioeconomic status, and cognitive ability for predicting important life outcomes. Perspectives in Psychological Science, 2(4), 313-345.

Sarracino, F. (2012). Money, sociability and happiness: Are developed countries doomed to social erosion and unhappiness? Social Indicators Research, 109, 135-188.

Sar1, E. (2016). Özgüven duygusu. (1. Bask1). Antalya: Net Medya Yayınc1lık.

Sarıboğa, V., Kılıç, E. D. and Serin, H. (2019). Sınıf öğretmenlerinin birey-örgüt uyumu üzerine bir araştırma. Uluslararası Toplum Araştırmaları Dergisi, 19(13), 95-115.

Scarpello, V. and Campbell J. P. (1983). Job satisfaction: Are all the parts there? Personnel Psychology, 36(3), 577-600.

Schepers, J., de Jong, A., Wetzels, M. and de Ruyter, K. (2008). Psychological safety and social support in groupware adoption: A multi-level assessment in education. Computers \& Education, 51(2), 757-775.

Schneider, B. (2001). Fits about fit. Applied Psychology. An International Review, 50, 141152. 
Servet, O. (2017). Mutluluğun Türkiye'deki belirleyenlerinin zaman içinde değişimi. Akdeniz Üniversitesi İktisadi ve İdari Bilimler Fakültesi Dergisi, 17(35), 16-42.

Sığrı, Ü. and Gürbüz, S. (2013). Örgütsel davranış. İstanbul: Beta Yayınevi.

Sousa, J. M. D. and Porto, J. B. (2015). Happiness at work: Organizational values and personorganization fit impact. Paidéia (Ribeirão Preto), 25(61), 211-220.

Sökmen, A. and Bıy1k, Y. (2016). Örgütsel bağl11ı, örgütsel özdeşleşme, kişi-örgüt uyumu ve iş tatmini ilişkisi: Bilişim uzmanlarına yönelik bir araştırma. International Journal of Informatics Technologies, 9(2), 221-227.

Şencan, H. (2005). Sosyal ve davranışsal ölçümlerde güvenilirlik ve geçerlik. Ankara: Seçkin Matbaa.

Toker, B. (2007). Demografik değişkenlerin iş tatminine etkileri: İzmir'deki beş ve dört yıldızlı otellere yönelik bir uygulama. Doğuş Üniversitesi Dergisi, 8(1), 92-107.

Turgut, T. and Çinko, M. (2017). Değerli insana “değer"li çalışmalar. İstanbul: Beta Yayınları.

Turunç, Ö. and Çelik, M. (2012). İş tatmini-kişi-örgüt uyumu ve amire güven-kişi-örgüt uyumu ilişkisinde dağıtım adaletinin düzenleyici rolü. IsGuc: The Journal of Industrial Relations \& Human Resources, 14(2), 57-78.

Turunç, Ö. and Çelik, M. (2010). Çalışanların algıladıkları örgütsel destek ve iş stresinin örgütsel özdeşleşme ve iş performansına etkisi. Journal of Management \& Economics, 17(2), 183-206.

Tümgan, C. (2007). Kamu örgütlerinde motivasyon ve iş tatmini. (Yüksek Lisans Tezi). Erişim adresi https://silo.tips/download/kamu-rgtlernde-motivasyon-ve-tatmn

Turkey Statistical Institute, Life Satisfaction Survey, (2020), Access address http://www.tuik.gov.tr/PreHaberBultenleri.do?id=33729

Tzeng, H. M. (2002). The influence of nurses' working motivation and job satisfaction on intention to quit: An empricial investigation in taiwan. International Journal of Nursing Studies, 39, 867-878.

Ulutaş M. (2011). Harmonik yönetim (1. Bask1). Konya: Ulvita Yayıncılık.

Uzunbacak, H. H. and Akçanakat, T. (2018). İşin anlamı, zindelik, mutluluk ve iştatmini ilişkileri üzerine görgül bir araştırma. Elektronik Sosyal Bilimler Dergisi, 68, 16911702 .

Van Vianen, A. E. M. (2000). Person-organization fit: The match between newcomers' and recruiters' preferences for organizational cultures. Personnel Psychology, 53, 113-149.

Vanderbilt, R. (2012). Building better businesses by closing the happiness gap. (2019), Access address https://www.fastcompany.com/1679491/building-better-businesses-byclosing-the-happiness-gap

Vatandaş, S. (2017). Felsefenin kadim bir konusu olarak ahlâk ve ahlaki eylemin amacı olarak "mutluluk". Journal of International Management and Social Researches, 4(7), 1-9.

Veenhoven, R. (1996). The study of life-satisfaction. Hungary: Eötvös University Press.

Verquer, M., Beehr, T. and Wagner, S. (2003). A meta-analysis of the relations between personorganization fit and work attitudes. Journal of Vocational Behavior, 63, 473-489.

Weiss, H. M. and Cropanzano, R. (1996). An affective events approach to job satisfaction. (Eds. Staw, B. M. and Cummings, L. L). Research in Organizational Behavior, 18, 1-74.

Wright, T. A. and Doherty, E. M. (1998). Organizational behavior 'rediscovers' the role of emotional well-being. Journal of Organizational Behavior, 19(5), 481-485. 
Xiaojun W. and Peilan, G. (2009). The application of person-organization fit to the practice of human resource management. Paper presented at the Fourth International Conference on Computer. https://doi.ieeecomputersociety.org/10.1109/ICCIT.2009.23

Yahyagil, Y. M. (2005). Birey-organizasyon uyumu ve çalışanların iş tutumlarına etkisi. Yeditepe Ünversitesi İ̈BF Işsletme Bölümü Dergisi, 6(24), 137-149.

Yıldırım, A. (2020). İş yeri mutluluğu üzerinde kişi-örgüt uyumunun etkileri. (Ed.), Yönetim Bilimleri içinde. Ankara: Akademisyen Kitabevi A.Ş.

Yıldız, H. (1997). Kur'an'da mutluluk. (Yüksek Lisans Tezi). Erişim adresi Ulusal Tez Merkezi https://tez.yok.gov.tr/UlusalTezMerkezi/tezSorguSonucYeni.jsp 